\section{Phytotoxic Reaction of Hawaiian Cut Flowers and Foliage to Hydrogen Cyanide Fumigation}

\author{
James D. Hansen, Harvey T. Chan, Jr.', Arnold H. Hara, and \\ Victoria L. Tenbrink \\ Hawaii Institute of Tropical Agriculture and Human Resources, University \\ of Hawaii at Manoa, 461 West Lanikaula Street, Hilo, HI 96720
}

Additional index words. ginger, heliconia, protea, anthurium, shelf life

\begin{abstract}
Phytotoxicity from hydrogen cyanide (HCN) fumigation was measured in several varieties of Hawaiian cut flowers and foliage (Zingiberaceae, Heliconia, Orchidaceae, Marantaceae, Lycopodiaceae, Agavaceae, Proteaceae) as a potential disinfestation treatment. Concentrations tested were $2500,3700,4600$, and $5500 \mathrm{ppm}$ HCN for $30 \mathrm{~min}$. All foliage and most heliconia were undamaged at fumigation levels of $\mathbf{5 5 0 0}$ ppm HCN; most protea and 'Midori' anthuriums were uninjured at $4600 \mathrm{pm} \mathrm{HCN}$; red and pink ginger were uninjured at $3700 \mathrm{ppm} \mathrm{HCN}$; and all pincushion protea showed phytotoxicity to $\mathrm{HCN}$. Red ginger was quickly damaged when exposed to sunlight immediately after treatment at $2500 \mathrm{ppm} H C N$. No injury was observed in simulated shipment tests of red ginger and 'Ozaki' anthuriums fumigated at $2500 \mathrm{ppm}$ HCN. Wet, red ginger flowers longer than $6 \mathrm{~cm}$ were damaged at $2500 \mathrm{ppm} H C N$, whereas shorter flowers were uninjured. Wet 'Ozaki' anthuriums showed phytotoxicity only at $4600 \mathrm{ppm}$ HCN. Wet, treated lycopodium and bamboo orchid foliage was not injured. The number of marketable days and shelf life of the treated plant material were estimated from the visual ratings.
\end{abstract}

Because of its tropical island climate, Hawaii has insect pests not found elsewhere in the United States. Hence, California, to protect its agricultural industries, prevents the introduction of new pests by inspecting Hawaiian floral commodities on arrival. Likewise, the U.S. Dept. of Agriculture examines shipments to the U.S. mainland. Contaminated shipments are either destroyed, returned to the original shipper, or routed to other locations. Japan has similar quarantine restrictions, but allows for the fumigation of suspected infested shipments (-Japan. Fumigation Eng. Soc., 1981). Thus, contami-

Received for publication 9 Feb. 1990. Journal Series no. 3434, the Hawaii Institute of Tropical AgricultureandHumanResources.Reference to brand or firm name does not constitute endorsement by the U.S. Dept. of Agriculture and the Univ. of Hawaii at Manoa over others of a similar nature not mentioned. We thank the following for providing plant material for our tests: E. Tanouye and Green Point Nurseries Inc. of Hilo, HI; T. Shiroma and W. Suzuki of Hilo; R. McDanold and Sonrise Tropicals of Pahoa, HI; Maui Branch Station, Univ. of Hawaii at Manoa, Kula. We also thank M.H. Taniguchi, E.S. Linse, and T.Y. Hata for their laboratory assistance. Funding for this research was provided in part by the Governor's Agr. Coord. Committee, State of Hawaii, Grant no. 89-1, and the U.S. Dept. of Agriculture under C.S.R.S. Special Grnt no. 89-34199-4420. The cost of publishing this paper was defrayed in part by the payment of page charges. Under postal regulations, thispaperthereforemustbeherebymarked advertsemen solely to indicate this fact.

'USDA-ARS Tropical Fruit and Vegetable Research Laboratory, P.O. Box 4459, Hilo, HI 96720 . nated shipments cause economically damaging disruptions and delays in marketing.

Hydrogen cyanide $(\mathrm{HCN})$ is a potential postharvest treatment to rid Hawaiian flowers and foliage of residual insects. This fumigant, which is highly toxic to insects (APHIS, 1980), has been used for treating dormant nursery stock, ornamental, and glasshouse plants (Monro, 1969). Hydrogen cyanide fumigation is currently approved by APHIS (1986) for treatments against specific insect pests of cotton, grain, and tobacco; cut flowers and foliage are not included. Although $\mathrm{HCN}$ is very toxic to humans and calculated by adding the ratings of two observers. mammals, it is readily detectable by a characteristic odor, and safety procedures for its use have been established (APHIS, 1980; Japan. Fumigation Eng. Soc., 1981; Monro, 1969). In Japan, from May to October, HCN at $2500 \mathrm{ppm}$ for $30 \mathrm{~min}$ is used as a general fumigant treatment on living plants and fresh fruits; a higher rate is used in the colder months (Japan. Fumigation Eng. SW., 1981). Very little is known of the phytotoxic effects of HCN fumigation on commercial cut flowers and foliage.

The objective of our study was to explore the feasibility of $\mathrm{HCN}$ fumigation as a postharvest treatment for Hawaiian cut flowers and foliage by measuring the phytotoxic effects at various concentrations.

Fumigation. All fumigation was done in 28.3-liter fiberglass chambers (Labconco, Kansas City, Me.) under z-ventilated hood in the laboratory. The entrance for each unit was a latched, sealed window. Inside were an electric fan for mixing gases during fumigation and a beaker holder. A latex septum in the _roof allowed airtight injection of solutions. The valved input and exhaust ports of each unit connected it to other chambers and to a pressurized air source.

To initiate fumigation, a measured amount of solid $\mathrm{NaCN}$ for the desired concentration (e.g., $0.153 \mathrm{~g} \mathrm{NaCN}$ for $2500 \mathrm{ppm} \mathrm{HCN}$ ) was placed in a beaker, then put on the holder within each chamber. The chamber door was sealed, valves closed, and an excess amount of concentrated sulfuric acid (e.g., $0.5 \mathrm{ml}$ $\mathrm{H}_{2} \mathrm{~S} \mathrm{O}_{4}$ for $0.153 \mathrm{~g} \mathrm{NaCN}$ ) was injected through the septum into the beaker to release the gas. Concentrations, based on the molecular weights and amounts of the reactive components, were calculated for 2500, 3700, 4600, and 5500 ppm HCN.

When the fumigation was complete, the valves were opened to allow pressurized air to flow through the chambers. The gas exited through a latex tube, the end of which was

Table 1. Description for phytotoxicity ratings of plant materials. Total damage score for an item was

\begin{tabular}{|c|c|c|}
\hline \multirow[b]{2}{*}{ Rating } & \multicolumn{2}{|c|}{ Attributes of plant parts } \\
\hline & Flower & Foliage \\
\hline 0 & No damage to petals or bracts. & No damage to stem and leaves. \\
\hline 1 & $\begin{array}{l}\text { Slight discoloration or very minor flaws } \\
\text { anywhere. }\end{array}$ & $\begin{array}{l}\text { Few leaves have slight damage, good ap- } \\
\text { pearance. }\end{array}$ \\
\hline 2 & Some discoloration, still marketable. & $\begin{array}{l}\text { More leaves with slight damage, generally } \\
\text { good appearance, still marketable. }\end{array}$ \\
\hline 3 & $\begin{array}{l}\text { Discoloration expanding }(\approx 10 \%) \text {; not } \\
\text { marketable, but still suitable for vase. }\end{array}$ & $\begin{array}{l}\text { Many leaves with slight damage or few leaves } \\
\text { with major damage, still with good ap. } \\
\text { pearance. }\end{array}$ \\
\hline 4 & $\begin{array}{l}\text { More discoloration }(10 \%-20 \%) \text {; vase life } \\
\text { questionable. }\end{array}$ & $\begin{array}{l}\text { More leaves with major damage, appearance } \\
\text { fair; vase life questionable. }\end{array}$ \\
\hline 5 & $\begin{array}{l}\text { Increased discoloration }(\approx 30 \%) \text {; definitely } \\
\text { not suitable for vase. }\end{array}$ & $\begin{array}{l}\text { Most leaves with some damage, appearance } \\
\text { fair to poor; not suitable for vase. }\end{array}$ \\
\hline 6 & Some discoloration throughout $(\approx 50 \%)$. & $\begin{array}{l}\text { Most leaves with major damage, appearance } \\
\text { poor. }\end{array}$ \\
\hline 7 & Much discoloration throughout $(\approx 70 \%)$. & $\begin{array}{l}\text { Much of foliage damaged or dead (» } 70 \%) \text {, } \\
\text { appearance very poor. }\end{array}$ \\
\hline 8 & Major discoloration throughout $(\approx 90 \%)$. & $\begin{array}{l}\text { Most foliage dead }(\approx 90 \%) \text {, few undamaged } \\
\text { areas. }\end{array}$ \\
\hline 9 & Entire flower discolored. & Foliage dead. \\
\hline
\end{tabular}


Table 2. Species list of tropical cut flowers and foliage tested for phytotoxicity to hydrogen cyanide.

\begin{tabular}{|c|c|c|}
\hline Commodity & Family & Species $^{\mathbf{z}}$ \\
\hline \multicolumn{3}{|l|}{ Ginger } \\
\hline Red & Zingiberaceae & $\begin{array}{l}\text { Alpinia purpurata (Vieill.) K. } \\
\text { Schum. }\end{array}$ \\
\hline Pink, Eileen McDonald & Zingiberacea & $\begin{array}{l}\text { Alpinia purpurata (Vieill.) K. } \\
\text { Schum. }\end{array}$ \\
\hline \multicolumn{3}{|l|}{ Heliconia } \\
\hline Andromeda & Heliconiaceae & Heliconia psittacorum L. f. \\
\hline Parakeet & Heliconiaceae & Heliconia psittaconum L. f. \\
\hline Parrot & Heliconiaceae & Heliconia psittaconum L. f. \\
\hline Sassy & Heliconiaceae & Heliconia psittacorum L. f. \\
\hline Lobster claw & Heliconiaceae & Heliconia bihai L. f. \\
\hline \multicolumn{3}{|l|}{ Foliage } \\
\hline Bamboo orchid (leafy stem) & Orchidaceae & $\begin{array}{l}\text { Arundina graminifolia (D. Don) } \\
\text { Hochr. }\end{array}$ \\
\hline Calathea (leaf) & Marantaceae & Calathea insignis Petersen \\
\hline Lycopodium (stem) & Lycopodiaceae & Lycopodium cernuum $\mathrm{L}$. \\
\hline Peacock ti (leafy stem) & Agavaceae & Cordyline terminalis (L.) Kunth \\
\hline \multicolumn{3}{|l|}{ Protea } \\
\hline Pink Mink & Proteaceae & Protea neriifolia $\mathrm{R}$. Br. \\
\hline Orange banksia & Proteaceae & Banksia prionotes Lindl. \\
\hline Yellow-green banksia & Proteaceae & Banksia speciosa R. Br. \\
\hline Pink frost banksia & Proteaceae & Banksia menziesii $\mathrm{R} . \mathrm{Br}$. \\
\hline Safari Sunset & Proteaceae & $\begin{array}{l}\text { Leucadendron salignum Berg. } \mathrm{x} \\
\text { L. laureolum (Lam.) Fourcade }\end{array}$ \\
\hline Scarlet Ribbon pincushion & Proteaceae & $\begin{array}{l}\text { Leucospermum cordifolium } \\
\text { (Salisb. ex Knight) Fourcade } \\
\text { x L. glabrum Phil. }\end{array}$ \\
\hline Sunrise pincushion & Proteaceae & $\begin{array}{l}\text { Leucospermum cordifolium } \\
\quad \text { (Salisb. ex Knight) Fourcade }\end{array}$ \\
\hline Hybrid 36 pincushion & Proteaceae & $\begin{array}{l}\text { Leucospermum lineare } \mathrm{R} . \mathrm{Br} \text {. } \\
\times[\text { L. conocarpodendron }(\mathrm{L} .) \\
\text { Buek } \times(\text { L. lineare } \times L \text {. } \\
\text { cordifolium })]\end{array}$ \\
\hline Hybrid 51 pincushion & Proteaceae & $\begin{array}{l}\text { [Leucospermum lineare } \mathrm{R} . \mathrm{Br} \text {. } \\
\times \text { L. cordifolium (Salisb. } \\
\text { ex Knight) Fourcade] } \times \text { L. } \\
\text { glabrum Phil. }\end{array}$ \\
\hline Anthurium & & \\
\hline Ozaki & Araceae & Anthurium andraeanum Lind. \\
\hline Midori & Araceae & Anthurium andraeanum Lind. \\
\hline
\end{tabular}

${ }^{2}$ Species names from Liberty Hyde Bailey Hortorium (1976).

Table 3. Damage scores of specific floral commodities for controls and those treated at various concentrations of $\mathrm{HCN}$ at $30 \mathrm{~min}$. (Differences in damage scores did not differ significantly for plants not listed.)

\begin{tabular}{lcccccr}
\hline & & & \multicolumn{2}{c}{ Damage score } & \\
\cline { 4 - 6 } & & & Control & Treated & & \\
Commodity & $(\mathrm{ppm})$ & Day & $\overline{\mathbf{x}} \pm$ SEM & $\overline{\mathbf{x}} \pm$ SEM & $t$ & df \\
\hline Lobster claw & 5500 & 4 & $3.0 \pm 0.4$ & $5.3 \pm 0.6$ & $3.00^{*}$ & 7 \\
Sunrise protea & 2500 & 1 & $1.6 \pm 0.2$ & $2.8 \pm 0.5$ & $3.25^{*}$ & 7 \\
Hybrid 51 protea & 4600 & 4 & $4.3 \pm 1.0$ & $8.3 \pm 1.0$ & $2.74^{*}$ & 7 \\
Scarlet ribbon & 3700 & 7 & $1.8 \pm 0.3$ & $10.3 \pm 0.9$ & $9.55^{* *}$ & 6 \\
Hybrid 36 protea & 2500 & 7 & $2.8 \pm 0.6$ & $8.8 \pm 0.4$ & $8.66^{* *}$ & 8 \\
Red ginger & 4600 & 4 & $5.2 \pm 0.2$ & $10.0 \pm 1.1$ & $4.15^{* *}$ & 8 \\
Red ginger & 4600 & 5 & $6.8 \pm 0.7$ & $6.0 \pm 0.6$ & $10.83^{* *}$ & 6 \\
Red ginger & 5500 & 5 & $6.8 \pm 0.6$ & $16.0 \pm 1.1$ & $7.40^{* *}$ & 6 \\
Pink ginger & 4600 & 3 & $4.7 \pm 0.7$ & $8.5 \pm 1.0$ & $3.21^{* *}$ & 10 \\
Pink ginger & 5500 & 3 & $4.7 \pm 0.7$ & $8.3 \pm 1.5$ & $2.26^{*}$ & 10 \\
\hline
\end{tabular}

**,*t Test significant at $P=0.01$ or 0.05 , respectively.

Table 4. Damage scores for red ginger flowers and leaves for controls and those exposed to sunlight for $1 \mathrm{hr}$ after being fumigated with $2500 \mathrm{ppm} \mathrm{HCN}$ for $30 \mathrm{~min}$.

\begin{tabular}{lcccr}
\hline \hline & Control & Treated & & \\
Plant part & $\overline{\mathrm{x}} \pm$ SEM & $\overline{\mathrm{x}} \pm$ SEM & $t$ & $\mathrm{df}$ \\
\hline Flowers & $6.0 \pm 1.1$ & $14.5 \pm 1.2$ & $5.29^{* *}$ & 6 \\
Leaves & $5.3 \pm 1.7$ & $11.5 \pm 0.3$ & $3.62^{* *}$ & 6 \\
\hline
\end{tabular}

${ }^{* *} t$ Test significant at $P=0.01$. submerged in water outside the laboratory. Chamber doors were opened after $15 \mathrm{~min}$ and the chambers were allowed to ventilate at least $15 \mathrm{~min}$ more before the fumigated material was removed.

Phytotoxicity. Plant material was treated at increasing concentrations of $\mathrm{HCN}$ and compared to untreated controls to determine phytotoxic levels. Visual ratings have been used to estimate plant damage and quality in flowers and foliage (Chase and Poole, 1987; Nell and Barrett, 1986; Neumaier et al., 1987). In our study, plant quality was estimated by two observers using a 10 -point scale to evaluate each item (Table 1). The damage score for every flower or foliage was the sum of the two ratings. Hence, $0=$ no injury, 4 $=$ limit of marketability, $8=$ limit of shelf life, and $18=$ complete discoloration or death. The plant material was rated before treatment and then twice weekly until the material was dead.

The evaluated plant material represented a variety of export Hawaiian cut flowers along with foliage leaves and stems (Table 2). Red ginger and 'Ozaki' anthuriums, high-volume export flowers, were used for several specific phytotoxicity tests. After treatment, the plant material was held in water under room conditions ( $\approx 20$ to $25 \mathrm{C}$; $\approx 40 \%$ to $60 \% \mathrm{RH}$ ). Among the floral products tested, ends of only ginger stems were removed $(\approx 3 \mathrm{~cm})$ before stems were placed in water. No preservative was added to the water.

Photosensitivity. Monro (1969) stated that $\mathrm{HCN}$, by interfering with physiological processes, may cause plants to be susceptible to injury in daylight, and he recommended that plants should be kept out of the sun several hours after treatment. If floral materials are to undergo $\mathrm{HCN}$ fumigation in Hawaii, they may be exposed to the tropical sun during normal handling procedures. To determine if HCN predisposes flowers to photosensitivity, treated red ginger was evaluated for sun damage. After eight flowers were treated at $2500 \mathrm{ppm}$ of $\mathrm{HCN}$ for 30 rein, half were exposed to afternoon sunlight for $1 \mathrm{hr}$ while the other half remained in the laboratory. Both groups were held in water, and leaves and flowers rated for phytotoxicity at regular intervals.

Simulated shipping. In another test, the effect of simulated shipping on $\mathrm{HCN}$-treated red ginger was evaluated. Three replications of five flowers were treated at $2500 \mathrm{ppm}$ $\mathrm{HCN}$ for $30 \mathrm{~min}$. These and five control flowers were bundled with masking tape. A plastic bag containing water-soaked cotton was attached to the stem-end of each bundle, then the bundles were placed in packing boxes containing shredded newspaper and plastic liners. Boxes were closed and held at room temperature. After 2 to 3 days, flowers were removed from the boxes, placed in water, maintained under normal room conditions ( $\approx 20$ to $25 \mathrm{C} ; \approx 40 \%$ to $60 \% \mathrm{RH}$ ), and rated for phytotoxic damage at regular intervals.

'Ozaki' flowers were, also evaluated under simulated shipping conditions. Four groups of five flowers each were treated for $30 \mathrm{~min}$ at $0,2500,3700$, or $4500 \mathrm{ppm} \mathrm{HCN}$ and 
Table 5. Damage scores after 1 week for red ginger flowers of two lengths that were untreated and those fumigated wet with $2500 \mathrm{ppm}$ $\mathrm{HCN}$ for $30 \mathrm{~min}$.

\begin{tabular}{ccc}
\hline $\begin{array}{c}\text { Length } \\
(\mathrm{cm})\end{array}$ & $\begin{array}{c}\text { Control } \\
\overline{\mathbf{x}} \pm \text { SEM }\end{array}$ & $\begin{array}{c}\text { Treated } \\
\overline{\mathbf{x}} \pm \text { SEM }\end{array}$ \\
\hline$<6$ & $4.4 \pm 0.6$ & $5.2 \pm 1.3$ \\
$>6$ & $4.8 \pm 0.7$ & $8.4 \pm 1.0$ \\
\hline
\end{tabular}

then placed in boxes containing shredded newspaper. The contents were moistened, the box closed and stored at room temperature ( $\approx 20$ to MC) for 3 days, then opened, and the flowers placed in water to be evaluated at regular intervals. warns that. HCN may damage moist plant materials, phytotoxicity was examined in treated, wet flowers and foliage. In one test, red ginger flowers of various lengths were measured, then divided into groups either greater or less than $6 \mathrm{~cm}$ long. The flowers were submerged momentarily in water, placed into chambers, treated for $30 \mathrm{~min}$ at 2500 ppm HCN, removed, placed in water, and rated along with controls of comparable lengths for phytotoxic effects. In another test, groups of five 'Ozaki' anthuriums were moistened and treated for $30 \mathrm{~min}$ at 0,2500 , 3600 , or $4500 \mathrm{ppm} \mathrm{HCN}$, then placed in water and rated at regular intervals for phytotoxicity. Similar tests were done with lycopodium and bamboo orchid foliage except that the highest concentration was $5500 \mathrm{ppm}$ $\mathrm{HCN}$. These plants were placed in water after treatment and rated twice weekly for phytotoxicity.

Data analyses. For each observation,
Wet floral products. Because Monro (1969)

damage scores were compared among treatments by analysis of variance (ANOVA), and individual treatments were compared to controls by $t$ tests to determine when and at what dosage significant damage occurred. Estimated number of marketable days and duration of shelf life after fumigation were determined by the amount of time for the average damage scores to reach 4 and 8 , respectively.

Averages, ANOVAs, and t tests were calculated by using MEANS, GLM, and TTEST procedures, respectively, of SAS for the personal computer (Statistical Analysis System; SAS Institute, Cary, N.C.).

Phytotoxicity. Damage scores did not differ significantly between controls and those treated for all foliages, the 'Midori' anthuriums, all heliconia, except lobster claw heliconia at 5500 ppm HCN (Table 3), and all of the banksia sunset and pink mink proteas. All Leucospermum cultivars were sensitive to HCN. 'Sunrise' protea showed significant damage at $2500 \mathrm{ppm} \mathrm{HCN}$ the day after treatment, and Hybrid 51 at 4600 ppm HCN on the 4th day (Table 3). Significant differences between controls and treated were observed a week after treatment at $3700 \mathrm{ppm}$ $\mathrm{HCN}$ for 'Scarlet Ribbon' and at 2500 pm HCN for Hybrid 36 (Table 3).

Damage ratings for red ginger, up to 3700 ppm HCN, did not differ significantly from their controls in seven tests. Significant differences occurred in flowers treated at 4600 and 5500 ppm HCN (Table 3).

Pink ginger was not significantly damaged at $2500 \mathrm{ppm} \mathrm{HCN}$ in three tests. In another test, pink ginger was not harmed at 3700 ppm $\mathrm{HCN}$, but was damaged at 4600 and

Table 6. Average number of marketable days for various tropical cut flowers and foliage after $30 \mathrm{~min}$ of $\mathrm{HCN}$ fumigation at various concentrations.

\begin{tabular}{|c|c|c|c|c|c|}
\hline \multirow[b]{3}{*}{ Commodity } & \multicolumn{5}{|c|}{ Period marketable (days) } \\
\hline & \multicolumn{5}{|c|}{ Concn (ppm) ${ }^{z}$} \\
\hline & 0 & 2500 & 3700 & 4600 & 5500 \\
\hline \multicolumn{6}{|l|}{$\overline{\text { Ginger }}$} \\
\hline Red & 4 & 4 & 3 & 2 & 2 \\
\hline Pink & 4 & 4 & ... & ... & ... \\
\hline \multicolumn{6}{|l|}{ Heliconia } \\
\hline Andromeda & 11 & 11 & 11 & 11 & ... \\
\hline Parakeet & 8 & 8 & 8 & 9 & $\ldots$ \\
\hline Parrot & 3 & 5 & 4 & ... & 3 \\
\hline Sassy & 5 & 5 & 5 & -.- & 5 \\
\hline Lobster Claw & 5 & 5 & 8 & $\ldots$ & 3 \\
\hline \multicolumn{6}{|l|}{ Foliage } \\
\hline Bamboo orchid & 3 & 3 & 3 & ... & 3 \\
\hline Calathea & 7 & 4 & 6 & $\cdots$ & 4 \\
\hline Lycopodium & 5 & 2 & 1 & --- & 2 \\
\hline Peacock ti & 6 & 7 & 12 & --. & 12 \\
\hline \multicolumn{6}{|l|}{ Anthurium } \\
\hline Ozaki & 8 & 7 & 8 & 1 & ... \\
\hline Midori & 27 & 29 & 23 & 25 & $\ldots$ \\
\hline \multicolumn{6}{|l|}{ Protea } \\
\hline Pink Mink & 9 & $\cdots$ & -.- & 8 & ... \\
\hline Orange banksia & 8 & ... & -.- & 8 & ..- \\
\hline Yellow-green banksia & 7 & $\ldots$ & ... & 7 & -.. \\
\hline Pink frost banksia & 7 & 7 & 8 & 8 & ... \\
\hline Safari Sunset & 12 & 11 & 11 & 10 & $-\cdots$ \\
\hline Sunrise pincushion & 4 & 2 & 2 & 2 & -.- \\
\hline Scarlet Ribbon & 16 & ... & 4 & 4 & $\ldots$ \\
\hline Hybrid 36 & 12 & 4 & 4 & 4 & ... \\
\hline Hybrid 51 & 4 & ... & 1 & 1 & $\ldots$ \\
\hline
\end{tabular}

${ }^{2}$ Dashed line indicates commodity not tested at concentration given.
5500 ppm HCN (Table 3).

Photosensitivity. Red ginger flowers and leaves showed significant damage 4 days after fumigation at $2500 \mathrm{ppm} \mathrm{HCN} \mathrm{(Table} \mathrm{4).} \mathrm{Thus,}$ the results of our study confirm that sunlight is destructive to freshly fumigated red ginger plants. To prevent potential phytotoxicity, treatment should be done in shaded areas, or treated materials should be kept away from sunlight for several hours (Monro, 1969).

Simulated shipment. In two simulated shipment tests, red ginger treated at 2500 ppm HCN was not significantly different from the controls. In another simulated test with 'Ozaki' anthuriums, only those treated at 4600 ppm HCN showed significant damage (Day 4: control damage score, $\overline{\mathrm{x}} \pm \mathrm{SEM}=0.4$ \pm 0.2 ; treated damage score, $\overline{\mathbf{x}} \pm$ SEM $=$ $10.6 \pm 0.4 ; t=21.747 ; \mathrm{df}=8, P<0.01)$; others treated at $2500 \mathrm{ppm}$ and $3700 \mathrm{ppm}$ were uninjured.

Wet plant material. In the phytotoxicity tests with wet red ginger, flowers longer than $6 \mathrm{~cm}$ were damaged at $2500 \mathrm{ppm}$ HCN (Table 5), but treated flowers $<6 \mathrm{~cm}$ long were not. Among wet 'Ozaki' anthuriums, only those treated at $4600 \mathrm{ppm} \mathrm{HCN}$ differed from the controls (Day 3: control damage score, $\overline{\mathbf{x}} \pm$ SEM $=1.0 \pm 0.4 ;$ treated damage score, $\overline{\mathbf{x}} \pm \mathrm{SEM}=4.6 \pm 0.8 ; t=3.882$, $\mathrm{df}=8, P<0.01)$. Wetting lycopodium and bamboo orchid foliage had no adverse effect. Hence, some moist plant materials can withstand HCN fumigation, even at high concentrations. The variation within ginger indicates that sensitivity may be due to plant morphology (e.g., size, degree of bloom, etc.) rather than genetics. Under commercial situations, representative samples should first be screened for phytotoxicity before large lots of the product are treated.

Duration of marketability days. For most of the treated plant materials, the estimated average number of days the products were marketable was unrelated to the concentration of the fumigant (Table 6). Even among the untreated, some of the commodities retained their freshness much longer than others. 'Midori' anthuriums, 'Sunset' protea, and 'Andromeda' heliconia were judged salable $>10$ days after treatment for all concentrations. The gingers, lycopodium, bamboo orchid, and 'Sunrise' pincushion had the least marketable time.

Duration of shelf life days. Shelf life tended to decline with increased HCN dosage (Table 7). Among the cut flowers, the 'Midori' anthuriums were the most long-lived. The peacock ti persisted, presumably because they established roots and grew new leaves. Some protea, although rated on their freshness, were attractive as dried flowers. Red ginger, 'Parrot' heliconia, and 'Sassy' heliconia were relatively short-lived. There was much variation among individuals, particularly the gingers and lycopodium; some flowers remained attractive long after others in the same treatment group had died.

The data for shelf life of the various plant materials can be interpreted to indicate the degree of sensitivity to HCN (Table 8). Most heliconia and foliages withstood up to 5500 
Table 7. Average number of shelf life days for diverse tropical cut flowers and foliage after $30 \mathrm{~min}$ of $\mathrm{HCN}$ fumigation at various concentrations.

\begin{tabular}{|c|c|c|c|c|c|}
\hline \multirow[b]{3}{*}{ Commodity } & \multicolumn{5}{|c|}{ Shelf life days } \\
\hline & \multicolumn{5}{|c|}{ Dosage $(\mathrm{ppm})^{2}$} \\
\hline & 0 & 2500 & 3700 & 4600 & 5500 \\
\hline \multicolumn{6}{|l|}{ Ginger } \\
\hline Red & 9 & 9 & 6 & 4 & 5 \\
\hline Pink & 10 & 10 & --- & $\cdots$ & $\ldots$ \\
\hline \multicolumn{6}{|l|}{ Heliconia } \\
\hline Andromeda & 15 & 16 & 15 & 14 & --. \\
\hline Parakeet & 11 & 11 & 11 & 11 & --- \\
\hline Parrot & 8 & 10 & 10 & $\ldots$ & 8 \\
\hline Sassy & 6 & 7 & 8 & -.. & 7 \\
\hline Lobster claw & 10 & 10 & 11 & --- & 8 \\
\hline \multicolumn{6}{|l|}{ Foliage } \\
\hline Bamboo orchid & 12 & 16 & 14 & --. & 12 \\
\hline Calathea & 14 & 7 & 15 & $\ldots$ & 11 \\
\hline Lycopodium & 9 & 3 & 7 & -.. & 9 \\
\hline Peacock ti ${ }^{y}$ & I & I & I & -.. & I \\
\hline \multicolumn{6}{|l|}{ Anthurium } \\
\hline Ozaki & 16 & 16 & 18 & 3 & $\cdots$ \\
\hline Midori & 31 & 31 & 33 & 33 & --- \\
\hline \multicolumn{6}{|l|}{ Protea } \\
\hline Pink Mink & 16 & $\ldots$ & -.. & 13 & --- \\
\hline Orange banksia & 18 & --- & --- & 19 & $-\cdots$ \\
\hline Yellow-green banksia & 12 & $\ldots$ & -.- & 12 & $\ldots$ \\
\hline Pink frost banksia & 13 & 12 & 12 & 12 & --- \\
\hline Safari Sunset & 14 & 13 & 14 & 14 & -.- \\
\hline Sunrise pincushion & 8 & 7 & 5 & 5 & --- \\
\hline Scarlet Ribbon & 21 & $\ldots$ & 6 & 6 & --- \\
\hline Hybrid 36 & 16 & 10 & 8 & 7 & -.- \\
\hline Hybrid 51 & 13 & $\ldots$ & 14 & 4 & $-\cdots$ \\
\hline
\end{tabular}

${ }^{2}$ Dashed line indicates commodity not tested at concentration given.

'I = indefinite; cutting takes root in water.

Table 8. Phytotoxicity of various tropical cut flower and foliage plants after $30 \mathrm{~min}$ of $\mathrm{HCN}$ fumigation at various concentrations.

\begin{tabular}{|c|c|c|c|c|c|}
\hline \multirow[b]{2}{*}{ Commodity } & \multicolumn{5}{|c|}{$\begin{array}{c}\text { Phytotoxicity }{ }^{2, y} \\
\text { Dosage (ppm) }\end{array}$} \\
\hline & 0 & 2500 & 3700 & 4600 & 5500 \\
\hline \multicolumn{6}{|l|}{ Ginger } \\
\hline Ręd & $\mathbf{S}$ & $\mathrm{S}$ & $\mathrm{C}$ & $\mathrm{H}$ & $\mathrm{H}$ \\
\hline Pink & $S$ & $S$ & $\ldots$ & $\cdots$ & $\cdots$ \\
\hline \multicolumn{6}{|l|}{ Heliconia } \\
\hline Andromeda & $\mathrm{s}$ & $S$ & $S$ & $\mathrm{~S}$ & $\cdots$ \\
\hline Parakeet & $\mathrm{S}$ & $\mathrm{S}$ & $\mathrm{S}$ & $\mathrm{S}$ & --. \\
\hline Parrot & $S$ & $\mathrm{~S}$ & S & $\cdots$ & $S$ \\
\hline Sassy & $S$ & $S$ & $S$ & --- & $S$ \\
\hline Lobster claw̌ & $\mathrm{S}$ & $\mathrm{s}$ & $\mathrm{s}$ & --- & $\mathrm{H}$ \\
\hline \multicolumn{6}{|l|}{ Foliage } \\
\hline Bamboo orchid & $\mathrm{S}$ & $\mathrm{S}$ & $\mathrm{s}$ & --. & $\mathrm{S}$ \\
\hline Calathea & $S$ & $\mathrm{~S}$ & $\mathbf{S}$ & --- & $\mathrm{S}$ \\
\hline Lycopodium & $\mathrm{S}$ & $\mathrm{s}$ & $S$ & --. & $\mathrm{S}$ \\
\hline Peacock ti & $S$ & $S$ & $S$ & --- & $S$ \\
\hline \multicolumn{6}{|l|}{ Anthurium } \\
\hline Ozaki & S & $\mathbf{S}$ & $S$ & $\mathrm{H}$ & --- \\
\hline Midori & $S$ & $\mathrm{~S}$ & $S$ & $\mathrm{~S}$ & --- \\
\hline \multicolumn{6}{|l|}{ Protea } \\
\hline Pink Mink & $\mathrm{S}$ & $\ldots$ & --. & $\mathrm{s}$ & -.- \\
\hline Orange banksia & $\mathrm{S}$ & ... & --- & $\mathrm{S}$ & ... \\
\hline Yellow-green banksia & $\mathrm{S}$ & $\ldots$ & --- & $\mathrm{S}$ & --- \\
\hline Pink frost banksia & $\mathrm{S}$ & $\mathrm{S}$ & $\mathbf{S}$ & $S$ & --- \\
\hline Safari Sunset & $\mathrm{S}$ & $\mathbf{S}$ & $\mathrm{S}$ & $\mathbf{S}$ & --. \\
\hline Sunrise pincushion & $\mathrm{s}$ & $\mathrm{C}$ & $\mathrm{H}$ & $\mathrm{H}$ & -.- \\
\hline Scarlet Ribbon & $\mathrm{S}$ & -- & $\mathrm{H}$ & $\mathrm{H}$ & $\ldots$ \\
\hline Hybrid 36. & $\mathbf{S}$ & $\mathrm{H}$ & $\mathrm{H}$ & $\mathrm{H}$ &.-- \\
\hline Hybrid 51 & $\mathrm{~S}$ & $\cdots$ & $\mathrm{C}$ & $\mathrm{H}$ & $\cdots$ \\
\hline
\end{tabular}

${ }^{2} \mathrm{~S}=$ safe, no significant damage compared to control; $\mathrm{C}$ = caution, some may have significant damage compared to control; $\mathrm{H}=$ harmful, significant damage compared to control.

'Dashed line indicates commodity not tested at concentration given. ppm HCN; the banksia and 'Pink Mink' proteas up to $4600 \mathrm{ppm}$. Differences in sensitivity between 'Ozaki' and 'Midori' anthuriums indicate that cultivar variation should be considered in future tests.

Wit and van de Vrie (1985) argued against $\mathrm{HCN}$ fumigation of cut flowers, citing an example of phytotoxicity in 'Anita' carnations. Our study showed that some Hawaiian floral products, particularly pincushion (Leucospermum spp.) protea, are not suitable for $\mathrm{HCN}$ fumigation. However, the majority of the plant materials we evaluated clearly withstood $\mathrm{HCN}$ fumigation at the rate required by Japanese quarantine regulations (2500 ppm HCN).

In a commercial operation, the product should be fumigated before packaging. In our simulated shipping tests, no additional phytotoxicity was observed when nonwetted flowers were fumigated. Floral commodities packed with damp materials, such as shredded paper, should not be fumigated. Hydrogen cyanide is readily absorbed by water, and the prolonged contact during shipping may damage the product.

Our study indicates that $\mathrm{HCN}$ fumigation at $2500 \mathrm{ppm}$ is appropriate as a potential treatment for certain Hawaiian cut flowers and foliage for export. More work is necessary to measure efficacy on major quarantine insect pests, to develop large-scale methodology suitable for production lines, and to refine procedures to maximize human safety as well as to minimize environmental risks.

\section{Literature Cited}

APHIS. 1980. PPQ treatment manual. Section IFumigants. Animal and Plant Health Inspection Serv. U.S. Dept. Agr. p. 5-8.

APHIS. 1986. PPQ treatment manual. Section VI, T300-Schedules for miscellaneous plant products. Animal and Plant Health Inspection Serv. U.S. Dept. Agr. p. 3, 7, 14, 17.

Chase, A.R. and R.T. Poole. 1987. Effect of fertilizer, temperature, and light level on growth of Syngonium podophyllum 'White Butterfly'. J. Amer. Soc. Hort. Sci. 112:296-300.

Japanese Fumigation Engineering Society. 1981. The text for the chief of plant quarantine fumigation operation. Tokyo (in Japanese)

LibertyHydeBaileyHortorium. 1976. Hortusthird. A concise dictionary of plants cultivated in the United States and Canada. 3d ed. Macmillan, New York.

Monro, H.A.U. 1969. Manual of fumigation for insect control. FAO Agr. Studies no. 79. Rome.

Nell, T.A. and J.E. Barrett. 1986. Influence of simulated shipping on the interior performance of poinsettias., HortScience 21:310-312.

Neumaier, E. E., T.M. Blessington, and J.A. Price. 1987.Effectoflightand fertilizer rate and source on flowering, growth, and quality of hibiscus. HortScience 22:902-904.

Wit, A. K. H., and M. van de Vrie. 1985. Fumigation of insects and mites in cutflowers for post harvest control. Med. Fat. Landbouww. Rijksuniv. Ghent 50:705-712. 